\title{
Bioleaching of Uranium Ore Containing Fluorite Using Acidithiobacillus ferrivoran, Acidithiobacillus ferrooxidans and Leptospirillum ferriphilum
}

\author{
Xiaolan $\mathrm{Mo}^{\mathrm{a}}$, Xiang $\mathrm{Li}^{\mathrm{b}}$, Jiankang $\mathrm{Wen}^{\mathrm{c}}$, Liulu Cai ${ }^{\mathrm{d}}$ \\ National Engineering Laboratory of Biohydrometallurgy, General Research Institute for Nonferrous \\ Metals, Beijing 100088 \\ ae-mail: mx10545@163.com, ${ }^{b} e-m a i l:$ kw07021x@163.com, ${ }^{\mathrm{c} e-m a i l: ~ k a n g 3412 @ 126 . c o m},{ }^{\mathrm{d}} \mathrm{e}-\mathrm{mail}:$ \\ cailiulu_03@163.com
}

Keywords: pitchblende; MLA; bioleaching; mixed culture;

Abstract. The results of MLA automated quantitative mineralogy system indicated the uranium ore used in this study was mainly composed of pitchblende $(0.47 \%)$, quartz $(64.91 \%)$, fluorite $(2.18 \%)$ and pyrite $(0.44 \%)$. The existence of fluorine-containing minerals plays a strong inhibition role of bacterial activity in the bioleaching process. The chemical characteristics showed that the content of U (IV) $(0.18 \%)$ was significantly higher than that of $U(V I)$, and the $U(I V) / U(V I)$ ratio was 4.5 . It is difficult to dissolve with sulfuric acid due to relatively higher $U$ (IV) in this uranium ore. The fluoride-tolerance mixed microbes were used for bioleaching of uranium, and the bioleaching and acid leaching experiments of fluoride-containing uranium ore were investigated in column reactor. The uranium extration rate of bioleaching column reached $72 \%$ in 38 days, using bioleaching have obvious advantages compare to conventional acid leaching $(65 \%)$.

\section{Introduction}

It is known that sulfuric acid and ferric ion are required in the process of uranium extraction. The former plays a role of leaching agent as uranium usually presented in ores in tetravalent state $U$ (IV), which must be oxidized to hexavalent state U (IV) before it can be dissolved in sulfuric acid solution. The latter is utilized as an effective oxidant which can easily oxide the insoluble U (IV) released from ore in to leached U (IV) by adding adequate amount of it $[1,2]$. It has been proved that bacteria of the genus Acidithiobacillus sp. and Leptospirillum sp., etc, which involved in these transformations, are capable of growing in highly acidic environment with highly heavy metal content $[3,4]$. Additionally, the bioleaching of a low-grade uranium ore using both single and mixed two cultures of Acidithiobacillus ferrooxidans and Acidithiobacillus thiooxidans has been studied in this process and the result showed that the best of uranium recovery were obtained with the mixed culture [5]. Various chemical oxidants such as $\mathrm{Fe}_{2}\left(\mathrm{SO}_{4}\right)_{3}, \mathrm{MnO}_{2}, \mathrm{NaClO}_{3}, \mathrm{H}_{2} \mathrm{O}_{2}$ are widely employed as a ferrous ion oxidant in uranium leaching processing [6]. However, the bio-oxidation is about $10^{5}-10^{6}$ times faster than the chemical oxidation [7]. Besides, the existence of fluorine-containing minerals plays a strong inhibition role of bacterial activity in the bioleaching process [8], which was a bottleneck of bioleaching technique applied in high fluorine content uranium ore. In the leaching process, the $\mathrm{F}^{-}$ion was combined with heavy metal ions such as $\mathrm{Al}^{3+}, \mathrm{Fe}^{3+}$ and $\mathrm{Mn}^{2+}$ ion to generate some complex compounds, and reduced its toxicity [9], so that it makes possible for bacteria to tolerate and grow in a high fluorine concentration [10].

\section{Materials and methods}

Materials. Uranium ores were collected from the 745 deposits (Guangdong, China) and crushed to $-6 \mathrm{~mm}$. The mineralogical composition was analyzed by MLA (Mineral Liberation Analyser) automated quantitative mineralogy system.

Column leaching experiment. The experimental apparatus are shown in Fig. 1. The columns were made of polyvinyl chloride (PVC). Layers of cobblestones in nylon net were placed at the bottom of the apparatus in order to supported the ore sample and enhance the permeability of leaching solution. The 
drip irrigation liquid was introduced through a feed solution tank at the top of the column. Another leachate solution tank beside the base of column was used to collect leachate solution. The irrigation (discontinuous) frequency and intensity was $12 \mathrm{~h} / \mathrm{d}$ and $10-15 \mathrm{~L} /\left(\mathrm{h} \cdot \mathrm{m}^{2}\right)$, respectively. The leaching process included stage of acid pre-leaching (19days) and bioleaching (19 days) in 1\# column. Control sample (2\# column) was set up of which leached by sulfuric acids liquid during 38 days.

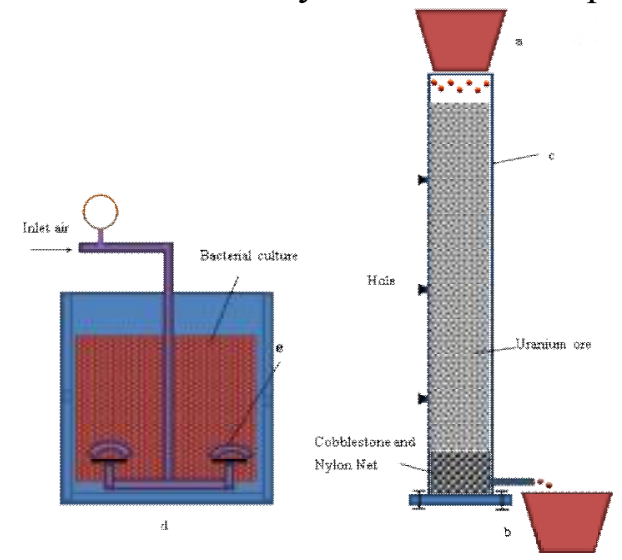

a- Feed solution tank; b- Leachate solution tank; c-Column reactor; d-Aeration tank; e- Aeration diffusors;

Fig. 1 Schematic diagram of experimental apparatus

Bacteria and its cultivation. The microorganisms was from National Engineering Laboratory of Biohydrometallurgy, which was isolated from the acid mine drainages (AMD) sample of 745 deposits. The microbiota was compositions of Acidithiobacillus ferrivoran (33.3\%), Acidithiobacillus ferrooxidans (56.8\%), and Leptospirillum ferriphilum (8.5\%), and others (1.4\%). Chemical composition of AMD (Concentration, g/L): $\mathrm{K}^{+} 0.02, \mathrm{Na}^{+} 0.07, \mathrm{Ca}^{2+} 0.56, \mathrm{Mg}^{2+} 1.30, \mathrm{Al}^{3+} 2.42, \mathrm{Fe}^{2+}$ $1.0, \mathrm{Fe}^{3+} 0.10, \mathrm{~F}^{-} 0.22$, and the tailing water (Concentration, $\mathrm{g} / \mathrm{L}$ ): $\mathrm{K}^{+} 0.98, \mathrm{Na}^{+} 1.37, \mathrm{Ca}^{2+} 0.60, \mathrm{Mg}^{2+}$ 1.06, $\mathrm{Al}^{3+} 1.92, \mathrm{Zn}^{2+} 0.01, \mathrm{Fe}^{2+} 1.40, \mathrm{Fe}^{3+} 0.6, \mathrm{~F}^{-} 2.04, \mathrm{Cl}^{-} 2.42$. The bacteria can adapt in the growth of the acid mine drainages and the tailing water. The inoculum was cultivated in an aeration culture tank (Fig. 1). Culture medium: ferrous sulfate was added as the energy resource for the microorganisms (ferrous concentration of $4.5 \mathrm{~g} / \mathrm{L}$ ). Parameter conditions of aeration culture: temperature $33^{\circ} \mathrm{C}, \mathrm{pH}$ $2.0-2.5$, and aeration intensity $2.0-3.0 \mathrm{~m}^{3} /\left(\mathrm{m}^{2} \cdot \mathrm{h}\right)$. When the bacterial culture attain to mature period (bacterial solution with $5.0 \mathrm{~g} / \mathrm{L} \mathrm{Fe}^{3+}$ ), the $\mathrm{pH}$ value was adjusted to 1.70 using $50 \% \mathrm{H}_{2} \mathrm{SO}_{4}$, as drip irrigation liquid in column bioleaching test.

\section{Results and discussion}

Mineralogical analysis. The MLA analysis of raw minerals was found that the uranium minerals is mainly composed of pitchblende $(0.47 \%)$, coffinite $(0.03 \%)$ and brannerite $(0.004 \%)$, and gangue minerals are mainly consisted of quartz $(64.91 \%)$, orthoclase $(10.89 \%)$, biotite $(9.42 \%)$, albite $(4.02 \%)$, calcite $(3.71 \%)$, fluorite $(2.18 \%)$, muscovite $(1.68 \%)$, pyrite $(0.44 \%)$ and dolomite $(0.39 \%)$, etc.. The distributions of the uranium minerals in each size intervals were determined and shown in Table 1, Table 2 and the SEM images of sample are shown in Fig. 2, respectively.

Table 1 Uranium distribution percentage of main minerals in different particle sizes

\begin{tabular}{cccccc}
\hline Particle size & Weight & \multicolumn{3}{c}{ Uranium Distribution $(\%)$} & \multirow{2}{*}{$(\mu \mathrm{m})$} \\
\cline { 3 - 5 } & $(\%)$ & Coffinite & Pitchblende & Brannerite & \\
\hline+150 & 0.47 & 8.17 & 91.42 & 0.41 & 100 \\
$-150 \sim+74$ & 14.12 & 7.67 & 91.3 & 1.03 & 100 \\
$-74 \sim+45$ & 30.58 & 8.25 & 87.54 & 4.21 & 100 \\
$-45 \sim+38$ & 5.10 & 8.69 & 90.89 & 0.41 & 100 \\
$-38 \sim+25$ & 1.76 & 5.35 & 89.54 & 5.12 & 100 \\
-25 & 47.97 & 2.98 & 97.02 & 0 & 100 \\
Total & 100.00 & 4.15 & 95.18 & 0.67 & 100 \\
\hline
\end{tabular}


Pithchblende, the principal uranium ore, has the ideal composition $\mathrm{UO}_{2}$. Although, pithchblende is always partially oxidized, with the $\mathrm{U}(\mathrm{IV})$ converted to $\mathrm{U}(\mathrm{VI})$, this ore sample degree of oxidation only reach $20 \%$. The sample of uranium ore contained $0.22 \%$ U. The content of U (IV) $(0.18 \%)$ was significantly higher than that of $\mathrm{U}(\mathrm{VI})$, and the $\mathrm{U}(\mathrm{IV}) / \mathrm{U}(\mathrm{VI})$ ratio was 4.5. The $\mathrm{U}$ (IV) is difficult to dissolve with sulfuric acid. Besides, rock characteristics plays an important role, high content carbonate, fluorite and low content sulfide mineral were unfavorable for extracting uranium by bioleaching. The beneficial and harmful minerals for the bioleaching are pyrite and fluorite respectively, but the content of pyrite is low. Therefore, the bacterial which have a certain tolerance of fluorine is required to carry out the bioleaching experimental study.

Table 2 Fluorine distribution percentage of main minerals in different particle sizes

\begin{tabular}{lllll}
\hline \multirow{2}{*}{$\begin{array}{l}\text { Particle size } \\
(\mu \mathrm{m})\end{array}$} & $\begin{array}{l}\text { Weight } \\
(\%)\end{array}$ & \multicolumn{2}{l}{ Uranium Distribution $(\%)$} & Tota \\
\cline { 3 - 4 } & $(\%)$ & Fluorite & Apatite & 1 \\
\hline+150 & 0.47 & 99.98 & 0.02 & 100 \\
$-150 \sim+74$ & 14.12 & 99.59 & 0.41 & 100 \\
$-74 \sim+45$ & 30.58 & 100 & 0 & 100 \\
$-45 \sim+38$ & 5.10 & 100 & 0 & 100 \\
$-38 \sim+25$ & 1.76 & 99.83 & 0.17 & 100 \\
-25 & 47.97 & 99.97 & 0.03 & 100 \\
Total & 100.00 & 99.93 & 0.07 & 100 \\
\hline
\end{tabular}
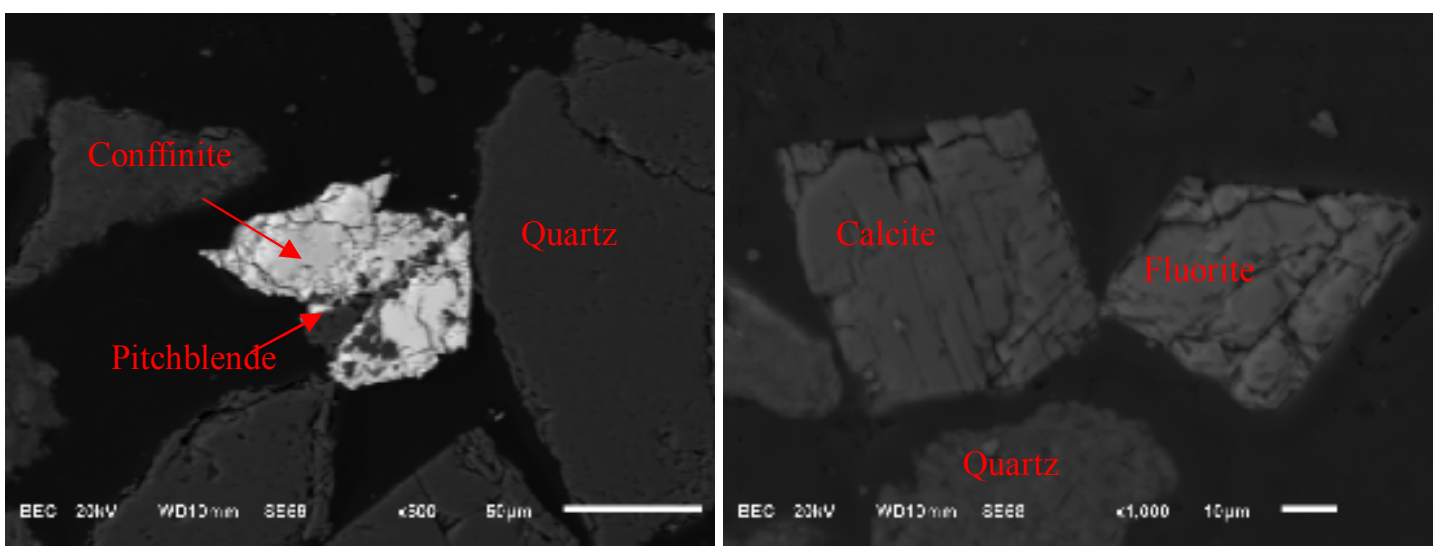

Fig. 2 SEM of ore

Column leaching experiment. The leaching solution ORP values of inlet and outlet in the column reactor are shown in Fig.3. The inlet ORP value of the solution was greater than $500 \mathrm{mV}$; which however, was lower than $320 \mathrm{mV}$ at outlet. This may due to the increase of the ferrous ion in the solution. When the acid consumption approaches to equilibrium, the ORP value changed less than before. In the second stage of leaching, as the initial ORP value of the leaching solution with bacteria was higher, the initial ORP value of $1 \#$ column feed liquor was about $100 \mathrm{mV}$ higher than that of $2 \#$ column. The changes of ORP values reflect the different leaching conditions of each column well. These results indicated that the higher redox potential of ore leaching solution, the better oxidation leaching effect of uranium.
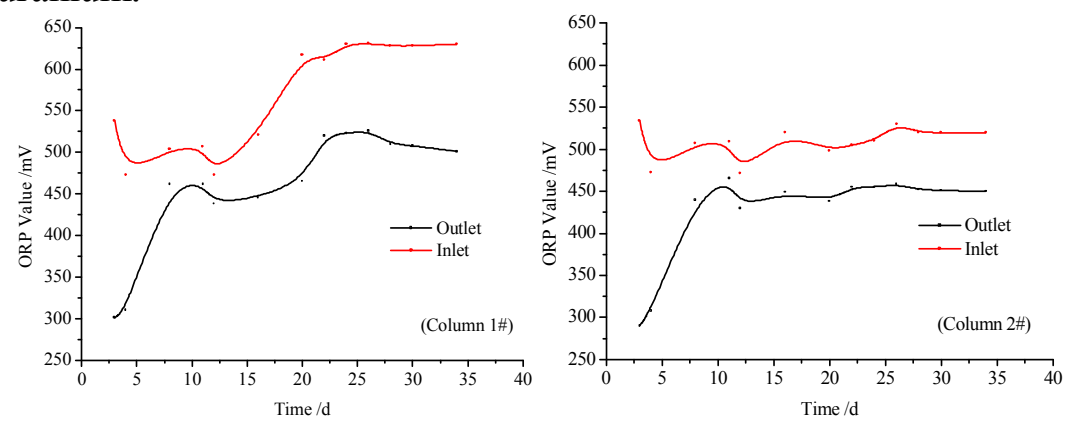

Fig. 3 Variation of ORP of leach solution with time 
By measuring the change of the concentration of uranium in the leaching solution, the leaching rate of each column was calculated and shown in Fig.4. The uranium leaching rate of 1\# and 2\# column reached $72 \%$ and $65 \%$ respectively, after 38 days leaching. The uranium leaching rate of $1 \#$ column was significant improved utilizing bacterial culture fluid in the latter stage of the leaching process.

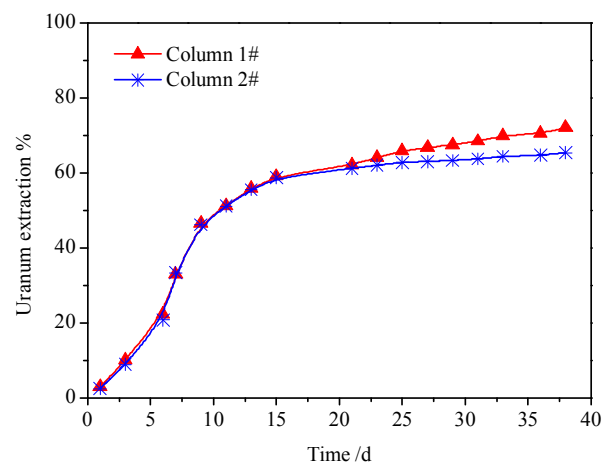

Fig. 4 Variation of leaching rate of uranium with time in different column

\section{Conclusions}

Using the fluoride-tolerance mixed culture composed of Acidithiobacillus ferrivorans, Acidithiobacillus ferrooxidans, and Leptospirillum ferriphilum, the bacterial leaching and acid leaching experiment of fluoride-containing uranium ore was conducted in column during 38 days. The uranium extraction rate in the bioleaching can reach $72 \%$, which exceeded more than $10.77 \%$ compared to that by traditional acid leaching. The high redox potential played a key role in accelerating uranium dissolution at the stage of bioleaching.

\section{Acknowledgments}

This work was financially supported by the National Natural Science Foundation of China (No.51404031) and the National High Technology Research and Development Program of China (No.2012AA061501).

\section{References}

[1] A Rashidi, J Safdari, R Roosta-Azad and S Zokaei-Kadijani. Annals of Nuclear Energy, Vol.5 (2012), p. 13

[2] Abhilash, S. Singh, K. D. Mehta, V. Kumar, B. D. Pandey and V. M. Pande. Hydrometallurgy, Vol.95 (2009), p. 70

[3] M. Eisapour, A. Keshtkar, M. A. Moosavian and A. Rashidi. Annals of Nuclear Energy, 54 (2013), p. 245

[4] B.C. Patel, D.R. Tipre and S.R. Dave. Bioresource Technology, 118 (2012), p. 483.

[5] A.B. Umanskii, A.M. Klyushnikov. J. Radioanal Nucl. Chem. 295 (2013), p. 151

[6] C. R. Edwards. JOM. Vol.52 (2000), p.12

[7] Abhilash, K.D. Mehta, V. Kumar, B.D. Pandey and P. K. Tamrakar. Energy procedia, 7 (2011), p. 158

[8] X. L. Mo, J. K. Wen, C. Y. Xu, B. Wu, B. W. Chen and H. Shang. Advanced Materials Research, 1130 (2015), p. 468

[9] T. C. Veloso, L. C. Sicupira, I. C. B. Rodrigues, L. A. M. Silva, V.A. Leão. Biochemical Engineering Journal, Vol.62 (2012), p. 48

[10] X.L. Mo, J.K. Wen, B.W. Chen, M.L. Wu, W.C. Gao. Chinese Journal of Rare Metals, Vol.39 (2015), p. 75 (In Chinese) 